\title{
Türkçede Ek Eylemin İşlevi: Ad Tümcelerini Yeniden Düşünmek
}

\author{
Mustafa Levent YENER ${ }^{1}$
}

\begin{abstract}
$\ddot{O} \mathbf{z}$
Türkçede, tümcelerin sınıflandırılması konusunda kullanılan ölçütlerden biri de yüklemdeki sözcügün türüdür. Sözcük türleri ise morfolojik, dizimsel ya da semantik ölçütler uygulanarak değişik sınıflandırmalara tabi tutulabilir; ancak üçünde de özellikle Türkçe için kesin olan ad ve eylem ayrımı bulunur. Bu iki temel sınıf açısından bakıldığında tümcenin ad tümcesi ve eylem tümcesi olarak sınıflandırılması doğru görünür; ancak yüklemin iş, oluş ya da durum bildiren bir sözcük olması nedeniyle ad olması mümkün müdür? Ek eylem, cevheri fiil, kopula, ana yardımcı eylem gibi terimlerle anılan er- $(>+\mathrm{i}-)$ eyleminin işlevine dikkat etmenin ve tekrar yorumlamanın sorunu başka bir şekilde açıklamaya olanak tanıyacağı açıktır. Ĕger +i- bir ek olarak kabul edilirse bir addan eylem yapma eki gibi işlediği iddia edilebilir; ancak geleneksel kanımız yapım eklerinin eklendiği sözcüğün temel anlamını değiştirdiği yönünde olduğundan yapım eki tanımımızı gözden geçirmek zorunda kalabiliriz. Yine geleneksel kabule dayanarak bir ek olduğu halde, +i- biçim birimini ek eylem/ yardımcı eylem olarak kabul edersek adlara uladığımız et-, kıl-, ol- gibi yardımcı eylemlerle kurup birleşik eylem olarak değerlendirdiğimiz sözcüklerin yüklem olduğu tümceleri eylem tümcesi; ek eylemle kurulanlara ad tümcesi demek de bir çelişki doğurmaktadır. İster ek ister yardımcı eylem olarak değerlendirilsin söz konusu biçim birimin bir adı eylemleştirdiği ve söz diziminde yüklem görevine soktuğu düşünülürse Türkçede bir ad tümcesinden söz etmek doğru olmayacaktır.
\end{abstract}

Anahtar kelimeler: Cümle türleri, sözcük türleri, yüklem, ad cümlesi, ek eylem, yardımcı eylem, kopula.

\section{The Function of Predicative Verb in Turkish: Rethinking the Nominal Sentences}

\begin{abstract}
One of the criterion held while classifying the sentences in Turkish is the class of the word used as predicate. Parts of speech can be determined by using morphological, syntactik or semantic criterions; but there's name and verb parts which is a absolute characteristic for Turkish. When we use this two basic parts, it seeems correct to determine the sentence classes as nominal and verbal sentences; but predicate should be the word that denotes action, occurrence or situation. In this condition is it possible to classify any sentence as nominal sentence? It's clear that paying attention to functions and interpreting the verb er- $\left(>+\mathrm{i}^{-}\right)$which is refered as predicative verb, copulla or main auxiliary verb may give us an opportunity to explain the problem in another way. If the verb - $i$ - is considered as suffix it can be claimed that it functions a derivational suffix; but in our conventional notion, a derivational suffix must change the main meaning. In this condition we will have to review our derivational suffix description. Although it's an suffix, based on conventional acceptance, if we evaluate the - $\mathrm{i}$ - morphem as an predicative verb/auxiliary verb, calling the sentences that we set up with the words that we evaluate as auxiliary verbs such as et-, kll-, ol-, verbal and others we set up with the predicative verb nominal sentences, causes a contradiction. Whether it is considered as a
\end{abstract}

Dr. Öğr. Üyesi, Çanakkale 18 Mart Üniversitesi, Fen Edebiyat Fakültesi, Türk Dili ve Edebiyatı Bölümü, mlyener@comu.edu.tr [Makale kayit tarihi: 3.7.2018-kabul tarihi: 15.8.2018] 
suffix or an auxiliary verb, it will not be accurate to mention a nominal sentence in Turkish, considering that the morphem mentioned sets a name on the predicate task in the syntax.

Key words: Sentence classes, parts of speech, predicate, nominal sentence, auxiliary verb, copula.

\section{Giriş}

Tümce ve söz dizimi; Türk dili çalışmalarının belki de en sorunlu, en tartışmalı konularından biridir. Tanımından sınıflandırma çalışmalarına kadar çoğu noktada araştırmacıların üzerinde düşünce birliğine varamadıkları konulardandır.

Dil bilgisi çalışmalarının atası olarak kabul edebileceğimiz Aristoteles, tümceyi "bağımsız, kesin bir anlamı olan ve her öğesi bir anlam taşıyan değişik ses bileşimlerinin (sözcüklerin) bağlantısı" (Aksan, 1989, s. 123) olarak tanımlamıştır. Bu tanımdan anlaşılacağı üzere ses ve yapı dizgelerinin kullanılmasıyla ortaya çıkan dizim, bir sonuç olarak anlamı üretir. Bu açıdan bakıldığında tümcenin değerlendirilebilmesi için çok boyutlu düşünmek gerektiği ortaya çıkmaktadır.

Türk dili çalışmalarında verilen belli başlı tanımlardan yola çıkarak söyleyebiliriz ki tümce; bir duyguyu, düşünceyi, olayı ya da isteği anlatmak için dinleyende soruya yer bırakmayacak şekilde açı, kendi içinde tutarlı, iş, oluş, kılış bildiren bir yargıya bağlanmış ve sözcük sayısı sınırlı olmayan bir sözcük dizisidir (Sezer, 1979, s. 54; Paçacığlu, 1987, s. 97-109; Aksan, 1989, s. 124; Korkmaz, 1992, s. 32; Gencan, 2001, s. 100; Ergin, 2002, s. 398; Delice, 2007, s. 133; Karahan, 2007, s. 9; Eker, 2011, s. 405; Sarıca, 2015).

Tümce tanımlarını, “Cümle Nasıl Tanımlanmalıdır?” adlı makalesinde değerlendiren Delice, tanımların yargı ve anlamın merkeze alınarak yapıldığını, tümcenin yapısal olarak yüklem etrafında şekillendiğini ve yargının herhangi bir yapıyla dile getirilebileceğini ifade eder. Bu nedenle "Cümle, bir yüklem ile -biri mutlaka özne veya nesne olmak koşuluyla- ona bağlı en az bir tamlayıcıdan oluşan ve bir, kılış, oluş veya durum bildiren söz dizimidir.” tanımını önerir (2012, s. 37-40).

Sözcüklerin türleri anlam bilgisel, biçim bilgisel ya da söz dizimsel kriterlere göre farklı şekillerde sınıflandırılabilir. Sınıflandırma ölçütü ne olursa olsun "çok az istisnalarla Türkçe kelime tabanları iki ana gruba ayrılır: Ad ve fiil. Bu kelime sinfflarından her biri, hepsi kendi kelime sinfflarıla kesinkes sınırlanmış, gramer ve türetme eklerinden ibaret özel bir gruba dahildirler.” (Grönbech, 2000, s. 18). Diğer dillerde bu ayrım Türkçedeki kadar kesin değildir. Örneğin İngilizcede face "yüz, çehre" - to face "karşılaşmak, yüzleşmek", find "bulma, bulgu keşif" - to find "bulmak, keşfetmek" gibi eş sesli kökler bulunurken Türkçede bu örnekler oldukça azdır ve bu eş seslilik, tarihî seslik değişimlere dayanır (Tekin, 1997, s. 50-66; Grönbech, 2000, s. 18).

Mantıksal olarak tanımlandığında adlar, evrendeki varlıklara karşılık gelen sözcüklerdir. Bunlar hareket bildirmezler; anlam yükü olarak varlıkların iç ve dış niteliklerini gösteren, söz diziminde sıfat, belirteç, adıl, ünlem, bağlaç, ilgeç gibi görevler alan sözcüklerdir. Adlar, tümce söz diziminde, durum ekleri alarak özne, nesne, dolaylı tümleç ve belirteç tümleci olurlar. Bunların hepsi tümcenin temel unsuru olan, yüklemi anlamca tamamlayan unsurlardır (Ergin, 2002, s. 280; Yener, 2007, s. 606-623). Adlar, "Fiil cümlesinden yüklemi ‘özne', 'nesne', 'dolaylı tümleç' ve 'açılama tümleci' olarak tamamlayan; isim cümlelerinde 'yüklem' olabilen ve onu 'nesne', 'dolaylı tümleç' ve 'açıklama tümleci' olarak tamamlayan ve sözcük öbekleri içinde yönetici olan sözcük dizisidir.” (Delice, 2012, s. 32). 
Eylem ise evrendeki hareketleri karşılayan sözcüklerdir. Varlıkların -yukarıda sözünü ettiğimiz gibibelirli bir zamanda, belirli bir yerde, belirli bir nesne üzerinde gerçekleştirdikleri hareketleri karşılarlar. Bu hareketler, varlıkların kılışları, oluşları ve duruşlarından oluşurlar ve eylemler de bunları işaretleyen sözcükler olarak karşımıza çıkar. Varlıklar kendi başlarına var olabilirlerken hareketler varlığa ihtiyaç duyacaklardır. Adlar tek başlarına anlam ifade edebilirlerken eylemler ancak adlarla birlikte anlam kazanacaklardır. Bu bağımlılıkları onların varlığın hareketinin gerçekleştiği zamanı ve hareketi gerçekleştiren varlığın şahsını belirten işaretlerle birlikte bulunmasını gerekli hâle getirir. Eylemler, söz diziminde sadece yüklem görevinde bulunurlar (Ediskun, 1992, s. 170; Ergin, 2002, s. 280, 398; Delice, 2012, s. 32;).

O halde -yeniden belirtmek gerekirse- Türkçe, iki temel sözcük sınıfından oluşur: Adlar ve eylemler (Krueger, 1961, s. 38-43; Johanson \& Csató, 1998, s. 90-91). Bu iki türün görevleri de buna bağlı olarak belirlenir. Grönbech bunu şu sözlerle tespit eder:

“Türkçe kelime kadrosunun ikiliği şuradan anlaşılır: Aksi bir olaya yani çekimli bir adın fiil olmasına, ad tabanının gerindiyum eki almasına rastlamıoruz. O hâlde dilin bütün yapısını kuran iki kelime sınıfı olduğunu kabul etmek zorundayı.” (Grönbech, 2000, s. 22)

Bu kadar kesin bir ayrım, doğal olarak sözcüklerin söz dizimsel ve biçim bilgisel özelliklerini etkileyecektir. Tür farklılıkları adların ve eylemlerin görevlerini farklılaştıracaktır. Adların tümcedeki görevlerini belirleyen eklerle eylemlerin tümcedeki görevlerini belirleyen ekler birbirlerinden farklı olacaktır. Biri için kullanılabilecek ekin diğeri için kullanılması mümkün olmayacaktır. Bu durumda, bu iki türün birbirlerinin görevlerini alabilmelerinin yolu; addan eyleme veya eylemden ada dönüşmeleridir.

Türkçe dilbilgisi çalışmalarında araştırmacıların vardığı ortak sonuca göre tümcenin asıl unsurları; tümcenin konusu olan özne ve yargı bildiren yüklemdir. (Ediskun, 1992, s. 328; Ergin, 2002, s. 398; Atabay, Özel, \& Çam, 2003, s. 20; Delice, 2007, s. 134; Erkul, 2007, s. 20; Aktan, 2009, s. 84; Karaağaç, 2011, s. 223; Sarica, 2015, s. 27).

Delice'nin “Cümle Nasıl Tanımlanmalıdır?” adlı çalışmasında ayrıca, diğer araştırmacılarla benzer bir şekilde, tümcenin temel unsurunun yüklem olduğu, eksiltili ya da eksiltisiz bir yapının söz diziminde tümce sayılabilmesi için yükleme yaslanması gerektiği ifade edilir. Delice'ye göre tümce bir gerçekliğe dayanmalıdır, bu gerçeklik ise canlı/cansız bir öznenin/kılıcının gerçekleştirdiği özneli eylemler olan kılış eylemleri ya da öznenin/kılıcının iradesine bağlı olmadan yani kendiliğinden gerçekleşen nesneli eylemler olan oluş eylemleri aracılığıyla söze dönüştürülür. Yine öznenin/kllıcının içinde bulunduğu durumların ise ek eylem ya da yardımcı eylem almış bir adla söze dönüştürüldüğünü iddia eder (2012, s. 39).

"Her tümcede bir özne, bir de yüklem bulunur. Özne ve yüklem, tümcede dilbilgisel araçlarla belirlenir. Örneğin özne tümcenin belirli bir yerinde (tümcenin başında veya başka bir yerinde) olandır; yüklem, üzerinde çekimsel kategori belirleyicileri (zaman, kip, kişi vb.) olandır.” (Uzun, 2004, s. 95).

Tümcenin oluşumu ve sınırları hakkında yapılan çalışmalarda eylemin merkeze alındı̆̆ı ve tümcenin iş, oluş, durum bildiren sözcük ve bunların gerçekleştirilebilmesi için zorunlu olan tamlayıcılardan oluştuğu kabul edilir (Uzun, 2004, s. 96). Fizik kuralları açısından bakıldığında tümcede yüklem olan yani iş, oluş bildiren- sözcük genellikle bir eylem olduğundan hareket ifade eder. Hareket, fizik kurallarına göre nesnenin yer değiştirmesidir. Nesnenin harekete geçmesi ise bir güce bağlıdır. Hareket, 
belirli bir zaman ve belirli yer içinde gerçekleşir. Hareketi ortaya çıkaran güç kaynağının tarzı da önemlidir. Bu durumda hareket; nesne, güç kaynağı, zaman ve mekânın zorunlu bir sonucu olarak ortaya çıkar (Gece, 1993, s. 99). Tümce; bu durumda, bir varlı̆̆ın, bir nesne üzerinde, belirli bir zaman içinde ve belirli bir yerde gerçekleştirdiği hareketin söze dönüştürüldüğü dilsel yapılardır. Temel unsurları da hareket ve hareketi gerçekleştiren varlıktır. Yani yüklem ve öznedir.

Tümcenin temel unsuru olarak kabul edilen yüklem, çekimli eylem halinde bulunan, yargının yüklediği iş, kılış, oluş ve vasfi içeren ve kılan, olan, vasıflanan kişi veya şeyi taşıyan sözcüğün tümce bilgisindeki adı olarak tanımlanır. (Korkmaz, 1992, s. 174; Banguoğlu, 1995, s. 520; Gencan, 2001, s. 103; Atabay, Özel, \& Çam, 2003, s. 20; Karahan, 2007, s. 14)

Tanımlarda konumuz açısından ortaklaşan özellikler yüklemlerin iş, oluş, kılış, durum; yani hareket bildirmeleri ve çekimli eylem oluşlarıdır. Dillerin söz varlı̆̆ında bu anlamları taşıyan sözcükler, eylemlerdir. "Bir kılışı, bir oluşu veya bir durumu anlatan; olumlu ya da olumsuz şekillere girebilen kelime" (Korkmaz, 1992, s. 61) olarak tanımlanırlar. Yapısal özellikleri itibariyle zaman ve kişi eklerini doğrudan üstüne alabilecek sözcüklerdir. Bu açıdan bakıldığında bütün yüklem tanımlarında çekimli eyleme vurgu yapılması doğaldır. Tümcenin gerekli koşulu olan zaman ve kişiye bağlılık; ancak eylem türündeki sözcüklerin yapısında mevcuttur. Yukarıda belirttiğimiz üzere eylemler sadece yüklem görevine girebilirler ve adların üstlendikleri görevleri üstlenebilmek için tür değiştirmeleri gerekir:

\begin{abstract}
"Yüklem, cümlenin tek temel unsurudur ve kelime türleri içinde yüklem oluşturmakla görevli kelime türü olarak karşımıza çıkan ve kip ve şahıs kavramı veren bir fiilden oluşmak zorundadır. ......Diğer kelime türleri yüklem olacaksa, önce kelime türü olarak yapım eki, yardımcı eylem veya ek-eylemlerle fiile dönüştürülmelidir -yani, cümlede yüklem mutlaka fiil olmak zorundadır.-" (Delice, 2002, s. 187188)
\end{abstract}

Bu özellikleri nedeniyle tümcenin yüklemi olarak eylemin temele alınması doğru olacaktır. Peki sözcük türü olarak yüklem olamayan adlar tümcede yüklem olamazlar mı? Yüklem tanımlarında cevher fiil/ ek eylem ya da yardımcı eylem almış adlardan bu nedenle söz edilir. Yukarıda ifade edildiği gibi ad türündeki sözcükler bir şekilde eyleme dönüştürülmelidirler.

\title{
1. Ek Eylemin İşlevleri, Dilbilgiselleşmesi ve Ekleşmesi
}

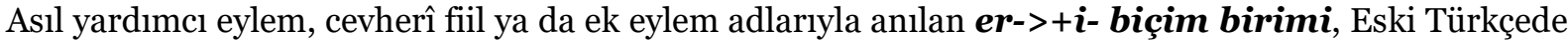
"olmak, bulunmak" anlamlarının yanında adları yüklemleştirme işleviyle de kullanılmıştır (KORKMAZ, 1992, s. 52). Görevleri bütün ad ve eylem şekillerinin sonuna gelerek birleşik eylemler kurmak ve adları yüklemleştirmek olarak belirlenen ek eylem, günümüzde $+\boldsymbol{i}$ - biçim birimi şeklinde karşımıza çıkmaktadır. Tek başına kesin ve belirli bir anlamı olmayan, mastar olarak kullanılamayan ve eylemlere gelen diğer çekim eklerini alamayan bu biçim birimden yeni bir ad ya da eylem gövdesi de üretilemez. Bu biçim birimin sadece şimdiki zaman, geniş zaman, görülen geçmiş zaman, öğrenilen geçmiş zaman ve şart çekimleri bulunur (Ergin, 2002, s. 314; Korkmaz, 2009, s. 703).

Genel anlayışa göre Türkçede ek eylem, temelde iki işlevde kullanılır:

\section{a. Adlara gelerek onları tümcede yüklem görevine getirirler:}

Tümcede yüklem görevine girebilen sözcükler, zaman ve kişi eki almak zorundadır. Bu dizimsel ve yapısal bir özelliktir. Dillerin dizimsel özellikleri ses bilgisel ve anlamsal özelliklerine göre daha yavaş değişim gösterir. 
BK D29 tokuz oguz mäni⿹ bodunum är-ti > Dokuz Oğuzlar benim halkım idi/halkımdı. (Tekin, 1995, s. 72)

G9 biz eki biy är-timiz>Biz iki bin idik/ bindik. (Tekin, 1995, s. 84)

KB-44 yagız yir yaşıl kökte er-di küsüş>Kara yerde de mavi gökte de aziz idi/ azizdi (Yusuf Has Hacib, 2007, s. 21).

KB-383 Karaykuda er-dim yaruttı tünüm > Karanlhkta idim/ karanlhktaydım gecemi aydınlattı (Yusuf Has Hacib, 2007, s. 53).

NF 324-13 mü'min er-ür siz (Eckmann, 1995, s. 225). > Müminsiniz.

NF 27-9 Mekkede er-dim (Eckmann, 1995, s. 20) >Mekke'de idim/Mekke'deydim.

YZ- 18 Var-ıdı ken'anda bir server gişi > Var idi/ vardı Kenan'da bir ulu kişi (Şeyyâd Hamza, 2008, s. 85).

YZ-2o Yidi yaşında i-di yūsuf nebì > Yusuf Peygamber yedi yaşıında idi/yaşındaydı (Şeyyâd Hamza, 2008, s. 85).

Ek eylemin buradaki işlevi, adları yüklemleştirmek olarak karşımıza çıkar. Yukarıda tartıştığımız üzere tümcenin asıl unsuru olan yüklem; iş, oluş ve durumu, kişi ve zamana bağlı olarak bildiren sözcügün tümcede aldığı görevdir. Adın yüklem görevine girmesi için ilk önce eylem olması gerekmektedir. Bu durumda ek eylem, tarihî ve yeni Türk dillerinde bir adı, kişi ve zamana bağlayarak yüklemleştirmek için kullanılır. Bu aslında bir tür söz yapımıdır.

Örnekler incelendiğine, AD+EK EYLEM+ZAMAN EKİ+KISŞI ADILI/ EKI şablonu açıkça görülür.

Ad ve bir yardımcı eylemden oluşan birleşmeler de Türkçenin eski dönemlerinden beri işlek olarak kullanılan birleşik eylem yapıları olarak karşımıza çıkar. Bunlar daha çok et-, ol-, kzl- gibi yardımcı eylemlerle kurulurlar. Bu eylemler, bağımsız birer eylem olarak varlık gösterseler de dilin gelişim aşamaları içinde anlamsal içeriklerini terk ederek dilbilgiselleşmiş unsurlar olarak karşımıza çıarlar (Öner, 2004, s. 283-289; Öner, 2006, s. 60-76; Öner, 2016, s. 9-14).

Orhon Türkçesinde; kagan bol- "hakan olmak", bay kıl- "zengin kılmak, zengin etmek" gibi örnekleri bulunan bu yapılar, daha çok ad/ sıfat+ yardımeı eylem biçiminde birleşmektedir (Tekin, 2003, s. 98-99).

Bu tip birleşmeler, Türkçede özellikle yabancı sözcüklerin artmasıyla birlikte, yabancı kökenli adların eyleme dönüştürülmesinde daha yoğun bir biçimde kullanılmaya başlanmıştır. Emret-, hapset-, iktizâ et-; namaz kıl-, talep kıl-, karar kıl-, âşikâr kıl-, muaf kıl-... Bu tip birleşik eylemlerde başlangıçta adların yüklemleştirilmesi için kullanılan Türkçe kökenli bol-, kzl-, kış- yardımcı eylemlerine, özellikle İslamiyet'in kabulünden sonraki döneme ait yapıtlarda daha yoğun olarak kullanılan et- ve yapeylemleri eklenmiştir (Öner, 2006, s. 60-76; Baydar, 2013, s. 59).

Türkçenin takip edebildiğimiz dönemlerinden beri adları ve ad öbeklerini yüklemleştirme konusunda kullandığı sistem hep aynıdır. Bunu yaparken er-, ol-, et- gibi eylemlere başvurur. Bu eylemler bugün Türkçede tek başlarına kullanılabildikleri gibi dilbilgiselleşerek birer çekim ya da yapım unsuru olarak kabul edilebilecek işlevlere de geçmişlerdir. $-\mathbf{i}+(<\boldsymbol{e r}-)$ ek eyleminin ol- eylemiyle işlev koşutluğu da birçok araştırmacı tarafından tespit edilmiştir. Ek eylemin ortaç ekiyle kalıplaştı̆̆ı "idük" biçiminin ve çekimlerinin Osmanlı Türkçesi ve bugünkü Türkmen Türkçesinde ol- eyleminin yerine kullanıldığı belirlenmiştir. "Özlerinin Salır Türkmenleridiklerini nıgtayarlar." (Kendilerinin Salır Türkmeni olduklarını belirtiyorlar). Benzer kullanım Osmanlı Türkçesinde ad+idük+iyelik eki şeklinde 
kullanılırken, bugün Türkiye Türkçesinde "nidüğü belirsiz” gibi kalıplaşmış bir sözde kullanılmaktadır (Öztürk, 2003, s. 77-85; Karabeyoğlu, 2007; Gedizli, 2013; Vural, 2013; Baydar, 2013; Özalan, 2014; Öner, 2016).

“Kagan boltım, kagan ertim" kullanımları yapı ve işlev açısından birbirlerine benzerlerken aralarında bu eylemlerin içeriklerinde karşıladıkları kavramlar nedeniyle anlamca farklılaşırlar:

"Eski Türkçede $a d+$ yardımcı fil kalıbında yardımcı fiil olarak kullanılan bol-, kll- yardımcı fiilleri dinamik kılınışta olup geçişli ya da geçişsiz oluşlarına göre ad + yardımcı fiil kalıbında adın karşlladığı varhı̆̆ın (nesne, nitelik, durum) ortaya çıkmasl, çıkarılması vb.; birleşik fiilin öznesinin birleşikteki adın gösterdiği varlı̆̆ (nesne, nitelik, durum) edinmesi, edindirilmesi vb. fonksiyonlarına; $e r$ - yardımcı fiili ise statik (durağan) kılınıșta olup (esas fiil halindeki mevcudiyet anlamıla) varlğı göstermek, işaret etmek, hüviyetini tanımlamak; ne, kim olduğunu, bir hâlde bulunmayı bildirmek görevleriyle bir varlığı (özneyi) o varlığın açıklayıcısı (yüklemi) durumundaki adlara (ve fiilin çekimli şekillerine) bağlama işlevine sahiptir ve bu yönleriyle diğerlerinden ayrılır." (Karabeyoğlu, 2007, s. 93)

Bu durum bugünkü Türk dillerinde de kendini gösterir (Özalan, 2014, s. 6-31).

AD+YARDIMCI EYLEM+ZAMAN EKİ+KIŞ̧I ADILI/ EKI şablonu benzer şekilde çalışır. İşlevi yine aynıdır: Adları yüklemleştirmek.

KT D4 anta kisrä inisi kaġan bol-mış ärinç. >Ondan sonra erkek kardeşleri hakan olmuşlar, şüphesiz (Tekin, 1995, s. 40).

KT D 24 bäglik urı oglun kul bol-th, eşilik kız oglun kü̈ bol-th (Tekin, 1995, s. 44)

> Bey olmaya layık erkek çocukların köle oldu, hanım olmaya layık kız çocukların cariye oldu.

NF 218-4 baḳtılar kim ot būstān bol-mış (Eckmann, 1995, s. 150) > Ateşin yeşillik bahçe olduğunu gördüler.

YZ-94 Rāàż ol-dılar ḳamusı gördi șevāb (Şeyyâd Hamza, 2008, s. 95).> Hepsi bu sözlere razı oldu.

\section{b. Birleşik zamanl eylemler kurarlar:}

BK D33 Türük bodun öl-teçi er-ti, yok bol-taçı er-ti (Tekin, 1995, s. 74).

KB- 83 Udır er-diy er-se tur aç emdi > Uyuyor idi isen/ uyuyorduysan şimdi kalk (Yusuf Has Hacib, 2007, s. 25).

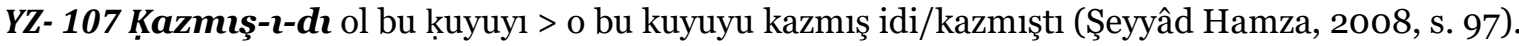

Örneklerden anlaşılacağı üzere, $+\boldsymbol{+}$ - (<er-) biçim biriminin öne çıkan ikinci işlevi ise birleşik zamanlı eylemler kurmaktır. Her ne kadar birleşik zaman çekimi olarak değerlendiriliyor olsa da bir eylemin iki farklı zamanda gerçekleşmesinin mantıksal olarak mümkün olmadığı açıktır. Birleşik zaman çekimlerinde ortaya çıkan ve zaman eki olarak sınıflandırdığımız ekler, aslında birer ortaç veya ulaç ekidir ve oluşturdukları her bir yapı, kiplik bir kategori olarak karşımıza çıkmaktadır (Gülsevin, 1997, s. 215-224; Turan, 2013, s. 133-144).

Birleşik zaman çekimi olarak adlandırdığımız bu yapıların şablonu şu şekilde çıarılabilir: EYLEM+ZAMAN EKİ+YARDIMCI EYLEM/ EK EYLEM +ZAMAN EKİ+KİŞİ ADILI/ EKİ. $\mathrm{Bu}$ yapılar, anlam ve işlevleri bakımından farklı yorumlansalar da eylem birleşmeleri olarak yorumlanabilirler. 
Türkçede birleşik eylem yapıları ad+yardımc eylem biçiminde karşımıza çıkacă̆ı gibi eylem+eylem biçiminde de oluşturulabilir. Eylem+eylem yapısındakilerin işlevleri ad+eylem yapısında olanlardan farklı olabilir; ancak farklı yardımcı eylemlerin kullanılmasına rağmen yapısal olarak benzer şablonlara yerleşiyor olmaları ilginçtir.

Eylem ve yardımcı eylemi bir araya getiren bir ulaç ve sonuna eklemlenen bir kişi adılı ile kurulan bu yapılar, Eski Türkçeden günümüze kadar tur- ya da yort- yardımcı eylemleri ile kurulan, özellikle şimdiki zaman anlamı veren yardımcı eylemlerdir. Bu dizimsel yapı içerisinde tur- ve yort- eylemleri, sırasıyla "kalmak, sabit bulunmak" ve "ilerlemek" gibi anlamlarıyla kullanılmıştır. Böylelikle bir eylemin şimdiki zaman içinde bulunduğunu ya da halen sürdüğünü ifade eden bu kiplik özellikleri verilmiştir. İzleyen süreçte ise bu eylemlerin önce anlam içerikleri boşalmış ve yardımcı unsurlar haline gelmişlerdir. Zamanla ekleşen bu eylemler günümüzdeki şekline; yani bugünkü morfolojik çekim unsurları haline gelmişlerdir. (ÖNER, 2004, s. 283-289; ÖNER, 2006, s. 60-76; ÖNER, 2016, s. 9-14)

bil-e tur-ur men, tap-a-dur mèn/ dè-ydür mèn, al-adrr mén/ söyle-ydir mén; bil-e yortr men; tapayortr mèn.... şeklinde yapılan şimdiki zaman çekiminin izleri bugün yeni Türk yazı dillerinde de görülmektedir. Söz konusu yardımcı eylemler, kimi Türk dillerinde aynen korunmuş olsa da kimilerinde de seslik değişikliklere uğrayarak sentaktik/ dizimsel çekim unsuru olmaktan çıkmış ve morfolojik çekim unsuru haline gelmişlerdir:

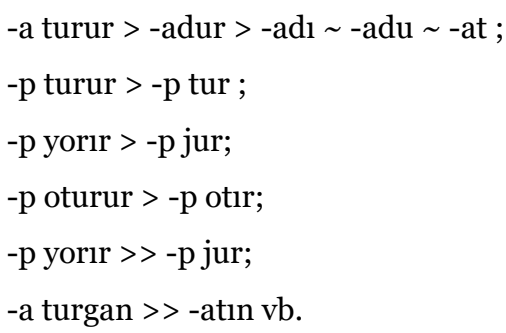

Türkiye Türkçesinde şimdiki zaman -a yorı- > -yor- biçimine gelişmiştir.

Türkçenin eylem çekimi yapısında da birleşik eylem şablonunun varlığı sezilir; çünkü en azından şimdiki zaman çekimi tur- ve yorr- eylemlerinin yardımcı eylem olarak kullanılmasıyla gerçekleştirilir: EYLEM+ULAÇ[=AD] +YARDIMCI EYLEM +ZAMAN EKI +KISŞI ADILI/EKİ.

Benzer yapı, özel kiplik ifadeleri oluşturmak amacıyla kurduğumuz ve kurallı birleşik eylem adıyla terimleştirdiğimiz sürerlik, yaklaşma ve yeterlilik birleşik eylemlerinde de bulunur. Farklı olarak tur-, ol-, et- gibi yardımcı eylemlerin yerine, anlamsal açıdan içi boşalarak yardımcı eylem işlevi kazanmış bir asıl eylem geçmiştir:

al-ı bir- "alıvermek" (Tekin, 1995, s. 60), uç-a bar- "vefat etmek, ölmek; uçup gitmek" (Tekin, 1995, s. 42), artat-u u- "bozabilmek, ylkabilmek" (Tekin, 1995, s. 68), ayt-u ber- "söyleyivermek" (Eckmann, 1995, s. 293), al-u ber- "alıvermek" (Eckmann, 1995, s. 236).

Bu örneklere bakıldığında da açıkça görülmektedir ki iki fiilin birleşmesi için bile bir tür adlaştırma olarak ifade edebileceğimiz bir ulaç ya da ortaç kullanma ihtiyacı duyulmaktadır. Yardımcı eylem işlevini kazanacak asıl eylemler bile adlaşmış yapıların üstüne getirilmektedir. Burada dikkat edilmesi gereken asıl ayrıntı, bu birleşmelerin kiplik anlamlarından çok, yapısal olarak bir çekim unsuru ya da söz dizimsel yapımda bir adı eylemleştirme işlevinde hangi özellikleri gösterdiğidir (Delice, 2002 , s. 19293; Tekin, 2003, s. 98-100; Öner, 2016, s. 9-14). 
Eylem ve yardımcı eylemi bir araya getiren bir ortaç ve sonuna eklenen bir kişi adılı/ eki ile kurulan bu yapılar, daha çok tasvirî eylemler oluşturmak için kullanılmıştır. Bizim bugün kurallı birleşik eylem olarak sınıflandırdığımız yapılar, eylemlere farklı kiplik anlamlar yüklemek için oluşturduğumuz birleşmeler olarak değerlendirilse de aslında daha çok, eylem çekimi olarak görev yapmaktadırlar. "iççer ol-, gel-ecek ol-, gel-miş ol-, gül-esi gel-” gibi ol- eylemiyle ya da asıl eylemlerden gelişmiş yardımcı eylemlerle kurulan kiplik unsurlar yapısal olarak değerlendirildiğinde asıl eyleme gelen eklerin zaman eki değil ortaç eki oldukları görülür (Gülsevin, 1997, s. 215-224).

Yukarıda belirttiğimiz üzere, ek eylem olarak adlandırdığımız biçim birimin bir başka işlevi de birleşik zamanlı eylemler kurmasıdır (Korkmaz, 2009, s. 702). Yani, bir eylemin üzerine gelen iki zaman ekini birleştirmesidir. Bir eylemin bu şekilde iki zamanda gerçekleştirilmesi oldukça mantıksız görünmektedir. Aslında bu işlev altında yapılanın Eski Türkçedeki EYLEM+ULAÇ+YARDIMCI EYLEM+ZAMAN EKİ+KIŞi ADILI/ EKI ya da EYLEM+ORTAÇ+YARDIMCI EYLEM+ZAMAN EKI + KİŞİ ADILI/ EKI formüllerine benzer şekilde sürdürülen bir çekim sistemi olduğu ve bugün kullandı̆̆ımız birçok ekin bu şekilde yardımcı bir eylemin ekleşmesinden doğduğu açıktır (GEDİLİ, 2013, s. 909).

\begin{abstract}
"Fonksiyonları ve tipleri aynı olan i- ve ol- fiillerine ayrı ayrı muamele ettiğimiz için, hem gramer öğretiminde, hem de derslerdeki morfolojik ve sentaks incelemelerinde ikilikler doğmaktadır. Şöyle ki; gel-ecekti (<gel-ecek i-di) çekiminin yapısı incelenirken gel- fiil -ecekti "Gelecek zaman(ın hikâyesi, 3. Teklik kişi)" (veya -ecek sıfat-fiil, i- ek-fiil, -di hikâye çekimi) olarak verilmektedir. gelecek oldu'da ise gel- fiil gel-ecek bu fiilin -ecek ile yapılmış sıfat-fiil (partisip) hâli, ol-du ol- fiilinin "görülen (bilinen) geçmiş zamanı" olarak gösterilir. Yani yukarıdaki çekimler, gramerimizde iki ayrı zaman olarak değerlendirilirler. "gel-ecekti" yapısında zaman, gramerlerimize göre "gelecek zaman"dır, "gel-ecek oldu"da ise "geçmiş zaman"dır. Oysa, ikisindeki -ecek de aynı -ecek'tir (sıfatfiil). İkisinde de -ecek üzerine fonksiyonlu birer morfem olarak müstakil filller (i- veya ol-) getirilmiştir." (Gülsevin, 1997, s. 221-22)
\end{abstract}

Bu yapılar için de şu şablon oluşturulabilir: EYLEM+ORTAÇ+YARDIMCI EYLEM+ZAMAN EKİ+KİŞI ADILI/ EKI.

Bu açıklamalardan yola çıkılarak yapısal bir yorum yapılacak olursa $+\boldsymbol{i}$-, ol-, et-, kzl- gibi yardımcı eylemler sıfat, zarf görevindeki adlara ya da ulaç veya ortaç eki almış eylemlere gelmekte ve onlara zaman, kip ve kişi unsurlarını yükleyerek yüklemleştirmektedir. Bu durumda ek eylem adını verdiğimiz biçim birimin adları yüklemleştirdiği ve onları kip ve kişiye bağlama işlevlerinin aynı yapı içerisinde tekrarlandı̆̆ı görülür.

Diğer yardımcı eylemlerle kıyaslanacak olursa ek eylemin dilbilgiselleşme sürecinde a) anlamsızlaşma (desemanticization) b) genelleştirme (extension) c) kategorisizleşme (decategorialization) d) ses indirgemesi (erosion) (Gündoğdu, 2016, s. 188) evrelerini geçirdiği görülür. Ancak en son evre olan ses indirgemesi, tam tamamlanmamış görünmektedir. Bir sözcük olarak ayrı yazılabildiği gibi bir ek gibi de kullanılabilmekte; hatta düşebilmektedir: Var idi // vardı ya da gelmiş idi // gelmişti. Günümüz standart Türkiye Türkçesinde genelde birleşik ve düşmüş biçimlerinin kullanımı yaygındır.

Bu durumda, ek eylem ya da cevherî fiil olarak adlandırdığımız $+\boldsymbol{i}$ - biçim biriminin bir ek olarak mı yoksa anlamsal açıdan içi boşalmış bir eylem, yani sözcük, olarak mı değerlendirileceği konusu kafa karıştırıcı olmaktadır. Ancak bugün er- "ulaşmak, bir duruma gelmek" anlamlarında bir bağımsız ve anlamlı eylemden ve $+\boldsymbol{i}$ - şeklinde bir de ekten söz etmek daha doğru olacaktır; çünkü biri sözlükte bir eylemin karşılığı iken diğeri dilbilgisinin bir unsurudur. Burada $+\boldsymbol{i}$ - biçiminin ayrı ya da bitişik yazılması, yazım ve ekleşme sürecinin tamamlanmamış olması ile ilgilidir. Benzer durum ilgeçlerde de 
görülür. Örneğin; ile sözcüğünün bir sözcük, ilgeç, olarak değerlendirilirken anlamca aynı olan; ancak biçimce ekleşmiş $+\boldsymbol{L A}$, bir durum eki olarak değerlendirilir. Burada tek fark, ile sözcüğünün ilgeç oluşudur. Bu nedenle eş zamanlı bir anlayışla bakıldığında $+\boldsymbol{i}$ - biçim birimi adların eylemler gibi kişi ve zaman eki alarak yüklemleşmesini sağlayan bir ek olarak değerlendirilmelidir; çünkü er- biçimi artık ayrı bir biçim birim olarak yaşamaya devam etmektedir.

Yapım ve çekimde eklerin kullanılması, Türkçenin en önemli özelliklerinden biridir. Eklerin ortaya çıkışında belirlenen en önemli özellik, bağımsız bir öğenin dilbilgiselleşmesi ve daha sonra ses değişikliklerine uğrayarak ekleşmesidir. Bu durum genellikle eylemle kurulan sözcük öbeklerinde gözlemlenir. Bizim ele aldığımız konu, ad+yardımcı eylem/ ek eylem biçimindeki ve -ek eylemin işlevine bağlı olarak- eylem+eylem biçimindeki öbeklerdir. Kuruluşları belli bir biçimsel sıraya uyan bu öbeklerdeki yardımcı unsurların tarihî gelişim içinde ekleştikleri rahatlıkla tespit edilebilir (Öner, 1999).

"Bir fiilin yardımcı fiil haline gelmesi çok tipik bir gramerleşmedir, yani bağımsız bir anlam ögesi olan sözün bağlı bir morfem halinde gramer görevi kazanmasıdır. Gramerde anlamıyla değil işleviyle yaşayan böyle bir yardımcı fiilin veya edatın ses ve biçim değişmeleri (ses düşmesi, kısalma vb.) ile bir eke dönüşmesi aynı zamanda çok ilgi çekici bir tarihî gramer olgusudur.” (Öner, 2004, s. 10)

Bu olgu, bugün ek eylem olarak adlandırdığımız +i- biçim birimi için de geçerlidir:

“...er- kökü ise VC tipindeki ünlü ile başlayan yani önden açık hece yapısıyla ekleşmeye çok daha uygundur. Nitekim er- kökünün Eski Türkçeden sonra izlediğimiz morfofonolojik tarihinde ünlü değişmesi (erdi > irdi); ünsüz erimesi (irdi > idi) ve nihayet kökte son kalan ünlüsünün kaybı ile tamamen ekleşmesi (güzel idi > güzeldi ) süreçlerini yakından gözlüyoruz.” (Öner, 2004, s. 10)

Benzer bir görüş de şu şekilde ifade edilmiştir:

"Yapı özellikleri bakımından yardımcı fiiller, isim+fiil ve fiil+fiil şeklindedir. Yapılarında genellikle iki ve üç ses bulunduran fiillerden oluşmaktadır. Çoğunluğu kök fiil olmakla beraber, türemiş fiillerden de yardımcı fiil bulunmaktadır. Tur-/-DIr, yor-/-yor; i- ve u- fiil örneklerinde görüldüğü gibi fiilden eke bir seyir izleyebilmektedirler." (Gedizli, 2013, s. 909)

+i- biçim biriminin bugün hâlâ ek eylem ya da yardımcı eylem olarak adlandırılmasının ve algılanmasının nedeni, söz konusu biçim birimin ekleşme sürecini tam olarak tamamlayamamış olması; yani bu sürecin hâlâ gözlemlenebiliyor olmasıdır.

Tur- yardımcı eyleminden gelişerek ekleşen $+\boldsymbol{D I r}$, yort- yardımcı eyleminden türeyen -yor biçim birimleri ek sayılırken $+\boldsymbol{i}$ - biçim biriminin halen ek eylem adıyla anılması, biçim birimin işlevsel ve yapısal değerlendirilmesinde kafa karışıklığı yaratmaktadır. Her hâlükârda +i-, artık bir eylem değil; bir ektir ve adları eylemleştirmek, onları yüklem görevine sokmak için kullanılmaktadır. Çok ilginç bir şekilde $+\boldsymbol{i}$ - biçim biriminin temel işlevi olan adları eylemleştirme/yüklemleştirme konusunda bütün araştırmacılar aynı fikirdeyken bu biçim birimi ek olarak kabul etmek konusunda tereddüt içinde olmaları düşündürücüdür. Yukarıda söz ettiğimiz, benzer işlevdeki birçok sözcüğün günümüz Türk dillerinde ekleştiği ya da ekleşme süreci içinde olduğu kabul edilirken $+\boldsymbol{i}$ - biçim birimine hem ek hem de eylem muamelesi yapmak bize yanlış görünmektedir. Bunun da ötesinde $+\boldsymbol{i}$ - biçim biriminin adları eyleme dönüştüren bir ek olduğunu kabul etmek daha doğru görünmektedir. Yoksa tutarlı olmak açısından bu tip unsurların hepsine, ek biçiminde de eylem biçiminde de olsa yardımcı eylem denmesi gerekir.

+i- biçim birimi bir tür değiştiricidir ve bir eylemin karşılayamadığı bir görevi yerine getirmek için bir adı eylemleştirir. Eski Türkçede er-, ol-, tur-, kzl- ile kurulan birleşik eylemlerin, yapısal olarak 
farklılık göstermeseler de, kılınışları açısından farklılık gösterdikleri açıktır (Özalan, 2014); ancak bize göre $+\boldsymbol{i}$ - biçim birimi, adları eylemleştirmek/ yüklemleştirmek göreviyle kullanılan yardımcı eylemlerle eş görevli olduğu söylenebilecek bir ektir. Bu terime bir de eylem kavramını eklemek gereksizdir.

\title{
2. Yapım Eki mi Yoksa Çekim Eki mi?
}

Türkçenin yapım ve çekim için en sık başvurduğu yollardan biri olan eklenmenin temel unsuru kabul edilen ek şöyle tanımlanır: "Cümle içinde kelimeler arasında geçici anlam ilişkileri kurmak veya yeni bir kelime türetmek üzere kök ve gövdelerin sonuna eklenen ses veya seslerden oluşan öge.” (Korkmaz, 1992, s. 52). Bu durumda, +i- biçim biriminin yardımcı bir eylem olarak değil de ek olarak kabul edilmesi durumunda ek sınıflandırmaları içinde nereye yerleştirileceği sorunu ortaya çıkacaktır. ${ }^{2}$

+i- biçim birimini yapım eki olarak kabul edecek olursak Türkçedeki söz yapım yollarından kısaca bahsetmek gerekir:

\begin{abstract}
“Türkçede söz yapımı için üç yol bulunur: 1. Morfolojik yol: söz+ek; 2. Sentatik yol: söz+yardımcı söz; 3. Semantik yol: yeni anlaml söz+yeni anlamlı söz. Türk yazı dilinin ilk örneklerinden itibaren isimden fiil yapan ek kadrosu şu şekilde tespit edilmektedir. $+a-/+e-;+l a-/+l e-;+t a-/+t e-;+$ rka-/ + irke-; +kvr-/+kir; +kl-/ +ki-; +ra/ +re-; +u-/+ü; +l-/+i-; +ad-/+ed-; +k; +ar-/+er-; +sura-/ +sire$;+s a-/+s e-;+s l-/+s i-$. İsmi filleştiren yardımcı fiilleri de çekim karakteri olan er- ana yardımcı fiilini dışarıda tutarak şöyle sıralıyoruz: bol- ol-; it- et-, eyle; yapmak (sonuncusu sadece Türkiye Türkçesi için).” (Öner, 2006, s. 61-62)
\end{abstract}

Konumuzun bir kısmını oluşturan ad+yardımen eylem/ ek eylem ve eylem+eylem karakterindeki birleşik eylemlerin büyük bir kısmının söz yapım yolları arasında sentaktik söz yapımına örnek olduklarını ve tarihî süreç içerisinde bu birleşiklerin yardımcı unsurlarının ekleştiği görülür. Bunların bir kısmı yapım kategorisinde değerlendirilirken bir kısmı çekim kategorisinde değerlendirilir. Ekleştikleri andan itibaren yapım, artık morfolojik yola dönüşür. Benzer durum çekim ekleri için de geçerlidir, örneğin; tur- yardımcı eyleminden gelişmiş $+\boldsymbol{D I r}$ ve yorı- yardımcı eyleminden gelişmiş Iyor ekleri morfolojik çekim unsurları olarak çalışırlar.

"Kelime kök ve gövdelerine getirilerek yeni kavramların yansıtılmasını, kavramlara karşılık yeni kelimeler yapılmasını sağlayan ek....Türkçede yapım ekleri addan ad, addan fiil, fiilden ad ve fiilden fiil türeten ekler olmak üzere dört tür oluşturur. Karşıtı çekim eki” (Korkmaz, 1992, s. 171) olarak tanımlanan yapım ekleri, Türkçede söz yapımı aşamasında en sık başvurulan yollardandır. Tanıma dikkat ettiğimizde yapım eklerinin her zaman bir tür değişimine neden olmadı̆̆ını; ancak anlam değiştirme işlevine daima sahip olduğunu görmekteyiz.

+i- biçim birimini çekim eki olarak kabul edeceksek aşağıdaki tanıma göre hareket etmeliyiz:

"Ad veya fiil soylu kelimeler üzerine gelerek, bağlı oldukları kelime gruplarına göre, kelimeler arasında durum, iyelik, çokluk, kip, zaman, şahıs, sayı vb. ilişkiler kuran ek" (Korkmaz, 1992, s. 36) olarak tanımlanan çekim eklerinin sözcükler arasında çeşitli ilişkiler kuran ekler olduğu görülür. Bu ekler, tür değişikliği yaratmadığı gibi, sözcük türüne özgüdürler. Durum eklerini eylemlere ekleyemediğimiz gibi zaman ve kişi ilişkisini belirleyen ekleri de adlara getirmemize imkân yoktur. Tıpkı tür kavramındaki katılık gibi çekim ekleri de bu katılığa uyarlar.

Tanımlara bakıldığında + $\mathbf{i}$ - biçim birimi, bir yandan sözcüğ̈̈̈n türünü değgiştirdiği için yapım eklerine benzerken diğer yandan sözcüğün temel anlamım değiştirmediği için de yapım eklerinden ayrilır. Bunun yanında özellikle adlara gelen ve onların dil bilgisel ilişkilerini ve

2 Eklerin değerlendirilmesi ve sınıflandırılması hakkında değerlendirmeler için bk. (Gülsevin, 2004). 
görevlerini belirleyen çekim ekleri arasında sayılabilir; ancak çekim ekleri de tür değişimine imkân vermez.

“Türkçede sözcükler arasındaki tür geçişkenliği genellikle yapım/türetim ekleriyle sağlanmaktadır. Sözcüklerde eklerle gerçekleşen tür değişikliği, duruma göre ek işlevi üstlenebilen sözcüklerle de mümkün olmaktadır. İsimler yeniden yeni kavramlar göstermek için isimleştirme ekleriyle isimleşirken, fiilleştirme ekleriyle de yeni bir fiil olurlar. Fiiller de aynı yöntemle isimleştirme ekleriyle yeni bir kavram ismi gösterdikleri gibi yeni bir eylemi göstermek için yeniden fiilleşirler. Sözcüklerdeki bu özellik leksik/sözlük açısından önemli bir çeşitlenme ve zenginleşme kaynağıdır. Sözcükler ise dilin sadece bir tarafını oluşturur. Sözcüklerin yetmediği ya da sözcük dıșı ihtiyaçların doğduğu durumlarda, sözcük işlevli sözcük birlikleri, sözcük işlevli yapılar kurarlar. Kelime grupları, söz öbekleri, sözcük birlikleri gibi farklı isimlerle anılan bu sözcük işlevli yapılar, anlam yönünden sözcügün işlevini yerine getirirken, işletim esnasında da işlevini karşladığı sözcük türünün bağlı olduğu kurallara uyarlar.” (Gedizli, 2013, s. 902)

Bu durumda +i- biçim birimini, yapım eki olarak kabul edip etmemek oldukça güç bir seçimdir; çünkü $+\boldsymbol{i}$ - biçim birimi adlara gelerek onların türce değişmelerini ve yalnızca eylemlere getirilebilen kip ve kişi eklerini almalarını sağlamaktadır. Tam da bu noktada $+\boldsymbol{i}$ - biçim biriminin tanımda geçen tür değişikliği yaratma özelliği açıkça ortaya çıkar. Bu açıdan bakıldı̆̆ında söz konusu biçim birim, bir yapım eki olarak kabul edilebilir; çünkü bir addan bir eylem üretmektedir. Sorun da buradan itibaren başlar. Bu biçim birim, yapım eklerinden beklenen anlam değişikliğini yaratma yeterliliğine sahip değildir. Eğer $+\boldsymbol{i}$ - biçim birimini, çekim eki olarak kabul edecek olursak bu defa da çekim eklerinin tür değiştirme özelliğinin bulunmaması noktasında tıkanırız; çünkü çekim ekleri adları ve eylemleri dil içinde çeşitli ilişki ve görevlere sokan bir ektir.

Öyleyse bizim ek sınıflandırmalarımız konusunda da bir sorunumuz olduğu açıktır. Bunu burada uzun uzun tartışmak yerine, ek sınıflandırmaları konusunda $+\boldsymbol{i}$ - biçim biriminin sınıflandırılması sorununu çözebilecek görüşleri gözden geçirelim:

Delice; bu konu üzerinde görüşlerini paylaştığı çalışmasında, ekler için önerdiği işlevsel bir sınıflandırma sunar. Onun sinıflandırmasına göre bu ekler "Yüklem Durum Ekleri" olarak değerlendirilir ve şöyle açılkanır:

“İsimleri cümle içinde YÜKLEM unsuruna dönüştüren, eskiden aslında birer yardımcı fiilken günümüz Türkçesinde fiilin kök anlamından tamamen uzaklaşarak bir ek gibi kullanılan; ama yine de zaman ve şahıs kavramlarıyla bir fiil imiş gibi çekimlenen bildirme ekleridir. + DIr: İsimlerden yüklem yapan ek: Bu kitap güzel-DíR; -ImIş: Bu kitap güzel-MİŞ.” (Delice, 2000, s. 227-228)

Delice, bu biçim birimleri durum ekleri başlığı altına yerleştirip "yüklem durum ekleri” olarak adlandırırken eklendikleri sözcüklerin edindikleri dizimsel görevleri baz almıştır. Bu açıdan bakıldığında tıpkı adlara gelerek onların tümce diziminde özne ve tümleç olmalarını sağlayan eklerin işlevlerine benzer bir şekilde $+\boldsymbol{i}$ - biçim birimi de adların yüklem olmalarını sağlamaktadır. Böylece bu biçim birimin anlamı değil; yaptığı iş göz önünde tutularak yapılacak bir sınıflandırmada yukarıdaki ikilem ortadan kalkacaktır.

Temel anlamı değiştirme konusundaki tartışmaları ortadan kaldırmak amacıyla bu biçim birimi, Delice'nin önerdiği şekilde yüklem durum eki ya da biçim birimin işlevini ifade ederken kullandığımız şekilde yüklemleştirici ek olarak kabul etmeyi daha pratik buluyoruz.

\section{Tümcede Yüklem Olarak Eylem}

Tümce tanımlarının hepsinde, tümcenin temel unsuru olarak kabul edilen yüklemin aynı zamanda çekimli bir eylem olarak da kabul edildiği görülmektedir. Türkçe, sözcük türleri bakımından kesin olarak 
iki ana gruba ayrılmıştır ve eylemlerin girebildiği görevlere adlar, adların girebildiklerine de eylemler girememektedir. Bu bakımdan bir adın yüklem olabilmesi için eyleme dönüştürülmesi gerekmektedir. Bunun için iki yol vardır. 1. Addan eylem yapan ekler getirmek, 2. Adları yardımcı eylemlerle birlikte kullanarak birleşik eylem oluşturmaktır. Türkçede söz yapımı ve çekiminin temeli bunlar üzerine kurulmuştur.

Eski Türkçede $\boldsymbol{a d}+\boldsymbol{e r}-/ \mathbf{b o l}-/ \boldsymbol{k a l}$ - biçiminde yapılan birleşik eylemler, yapısal olarak özellikle zarf ve sıfat görevine girebilecek adlara gelerek onları yüklemleştirir. Bu yardımcı eylemlerin Türkçenin tarihi boyunca arttığı; ancak birleşme sistemi açısından herhangi bir değişimin olmadığı açıktır. Yukarıda bahsedildiği üzere sistem, Türkçenin tarihi boyunca aynıdır. Bugün sadece seslik ya da anlamsal değişiklikler bulunmaktadır. Dizim sistemi neredeyse benzer şekilde sürmektedir.

Ad+ol-/ et-/ kal-... gibi yapılar ve eylem+ulaç/ortaç+eylem şeklindeki yapılar, biçimsel olarak birleşik eylem olarak kabul edilirler. Bunlar kiplik, kılınış, görünüş ve çatı özellikleri açısından incelenirler. Et-, ol-, kal-, yap- eylemleri ve yardımcı eylem olma özelliği kazanmış birçok eylem; dizimsel, işlevsel ve anlamsal özellikleri açısından değerlendirilmiştir. Her biri için farklı işlevsel ve anlamsal özellikler belirlenmişken dizimsel özellikleri açısından aynı oluşları, birleşik eylem türetmenin tek bir yolu olduğunu göstermektedir.

\begin{tabular}{|c|c|c|c|c|}
\hline AMAÇ & ASIL UNSUR & \multicolumn{3}{|c|}{ YARDIMCI UNSURLAR } \\
\hline EYLEM ÇEKIMII & EYLEM+ULAÇ[=AD] & $\begin{array}{l}\text { +YARDIMCI } \\
\text { EYLEM }\end{array}$ & $\begin{array}{l}\text { +ZAMAN } \\
\text { EKİ }\end{array}$ & $\begin{array}{l}\text { +KISISI ADILI/ } \\
\text { EKİ }\end{array}$ \\
\hline EYLEM ÇEKIMII & EYLEM+ORTAÇ[=AD] & $\begin{array}{l}\text { +YARDIMCI } \\
\text { EYLEM }\end{array}$ & $\begin{array}{l}\text { +ZAMAN } \\
\text { EKİ }\end{array}$ & $\begin{array}{l}\text { +KíSí ADILI/ } \\
\text { EKİ }\end{array}$ \\
\hline $\begin{array}{l}\text { BİRLEŞİK ZAMANLI } \\
\text { EYLEM ÇEKIMİ }\end{array}$ & EYLEM+ZAMAN EKİ & $\begin{array}{ll}\text { YARDIMCI } & \\
\text { EYLEM/ } & \text { EK } \\
\text { EYLEM } & \end{array}$ & $\begin{array}{l}\text { +ZAMAN } \\
\text { EKİ }\end{array}$ & $\begin{array}{l}\text { +KíSí ADILI/ } \\
\text { EKİ }\end{array}$ \\
\hline EYLEMLEŞTİRME & $\mathrm{AD}$ & $\begin{array}{l}\text { +YARDIMCI } \\
\text { EYLEM }\end{array}$ & $\begin{array}{l}\text { +ZAMAN } \\
\text { EKİ }\end{array}$ & $\begin{array}{l}\text { +KİŞI } \\
\text { ADILI/EKİ }\end{array}$ \\
\hline EYLEMLEŞTİRME & $\mathrm{AD}$ & +EK EYLEM & $\begin{array}{l}\text { +ZAMAN } \\
\text { EKİ }\end{array}$ & $\begin{array}{l}\text { +KİSİं } \\
\text { ADILI/EKİ }\end{array}$ \\
\hline
\end{tabular}

Amaç, ister eylem çekimi yaparak kiplik ifadeler oluşturmak isterse bir adı yüklemleştirmek olsun yardımcı eylemler, bir adın üzerine getirilmekte ve bu adın eylemleşerek yüklem görevinde kullanılmasını sağlamaktadır.

Bu yapılar değerlendirilirken ad+yardımce eylem şeklinde kurulan emret-, hapset-, iktizâ et-; namaz kıl-, talep kıl-, karar kıl-, âşikâr kıl-, muaf kıl-, yok ol-, yok et- gibi eylemler, birleşik eylem olarak kabul edilir. Yine eylem+ulaç+eylem şeklinde , bilebil-, yapıver-, düşeyaz-, gidekoy-, yapadur- gibi birleşik eylemler kuralh birleşik eylem olarak adlandırılırlar. Benzer şekilde oluşturulmuş içer ol-, geçecek ol-, gelmiş bul- gibi eylem+ortaç+eylem yapıları da birleşik eylem olarak tanımlanırlar.

Dizim ve işlev olarak aslında hiçbir farkı bulunmayan $\boldsymbol{a d}+\boldsymbol{i}$ - şeklinde kurulan eylemler genellikle birleşik eylem kategorisinde değerlendirilmezler; fakat $+\boldsymbol{i}$ - biçim birimi için ana yardımcı eylem ya da ek eylem terimi kullanılır. Bu çalışmalarda, tur- yardımcı eyleminden gelişerek ekleşen +DIr, yorı- yardımcı eyleminden türeyen -yor biçim birimleri ek sayllırken $+\boldsymbol{i}$ - biçim birimi, ek sayılmaz. Söz konusu yapının işlevi, adların yüklemleştirilmesidir denilebilir. 
Et-, ol- kal-yardımcı eylemleri ile bir adın oluşturduğu öbekler eylem olarak kabul edilirken aynı işlevle kullanılan; ancak kılınışları açısından farklılıkları olduğu ifade edilen $+\boldsymbol{i}$ - biçim birimiyle bir adın oluşturduğu dizimlerin eylem olarak kabul edilmemesi bir başka çelişki olarak karşımıza çıkmaktadır.

Yüklem için bir eylemin bulunması şartı, bu durumda tekrar gözden geçirilmelidir. Çünkü ad+işeklinde oluşturulmuş yapılar eylem sayılmazlarsa yüklem olmaları mümkün olmaz. İster birleşik eylem olarak tanımlansın isterse tanımlanmasın bu tür yapılar yüklem görevine girmektedir. Zaten $+\boldsymbol{i}-(<\boldsymbol{e r}-$ ) biçim biriminin Türkçedeki görevi, adları eylem türüne geçirmek ve onların kişi ve zaman eklerini alarak yüklem olmalarını sağlamaktır.

Bize göre, bu eki alan adlar, birleşik olarak da kabul edilseler; türemiş olarak da kabul edilseler eylemdir ve eylem kategorisinde değerlendirilmeleri gerekmektedir.

\section{Yükleminin Türüne Göre Tümce Türleri}

Tümce sınıflandırmaları konusunda kullanılan ölçütler şunlardır3: Yükleminin türü, yargı sayısı, çatı özellikleri, anlam özellikleridir. Bizim konumuzun sınırları içindeki yükleminin türüne göre tümceleri değerlendireceğiz.

Tümceler yüklemlerine göre sınıflandırılırken alınan ölçüt, yüklem olan sözcügü̈n tür açısından mensup olduğu sınıftır. Buna göre, iki temel sözcük sınıfından eylemin yüklem olduğu tümceler, eylem tümcesi, $\boldsymbol{a d}+\boldsymbol{i}$ - biçim birimi ile kurulmuş tümceler ise ad tümcesi olarak yorumlanır.

Eylem tümcesi "yüklemi çekimli fiil olan cümle” olarak tanımlanır (Korkmaz, 1992, s. 61). Yüklemin, yapılan tanımlarına bakıldığında, zaten çekimli bir eylem olması gerekmektedir.

Ad tümceleri, yüklemi ek eylem almış bir ad ya da ad öbeği olan tümcelerdir. Bunlar, genellikle özne ve yüklem olmak üzere iki öğeli olsalar da bulunma bildiren yer tamlayıcıları ve zaman zarfları da içerebilirler. Ayrıca ad tümcelerinde nesne de bulunmaz; +i- biçim birimi durum bildiren ereyleminden geliştiğinden bu durum gayet doğaldır (Banguoğlu, 1995, s. 535-538; Ergin, 2002, s. 403; Atabay, Özel, \& Çam, 2003, s. 79-90; Karahan, Türkçede Söz Dizimi, 2007, s. 96-99; Aktan, 2009, s. 110-111; Karaağaç, 2011, s. 246-249; Özkan \& Sevinçli, 2013, s. 157-161; Sarıca, 2015, s. 117-120).

Tanımlarda dikkati çeken husus, $+\boldsymbol{i}$ - biçim biriminin ek eylem olarak durum bildirmesi nedeniyle nesne, uzaklaşma ve yaklaşma bildiren yer tamlayıcılarını alamamasıdır. Araştırmalar, bu biçim birime eylem olarak muamele etmekte, durum eylemi olarak tanımlamakta; ancak bu tümceleri, ad tümcesi olarak değerlendirmektedir (Banguoğlu, 1995, s. 535; Ergin, 2002, s. 403; Karaağaç, 2011, s. 246).

Yukarıda belirttiğimiz üzere, tümcenin temel öğesi olan yüklemin, zamana ve kişiye bağlanmış bir hareket içermesi bulunması gerektiği kabul edilmiştir. Bu durumda yüklem, eylem türünde bir sözcük olmalıdır.

Sözcük türü olarak ele alındığında Türkçede ad ve eylem türündeki sözcüklerin dizimsel görevleri ve bu görevlere girebilmek için alabilecekleri ekler neredeyse kesin bir şekilde belirlidir. Bu durumda adın eylem ya da eylemin ad görevine girebilmesi için tür değiştirmeleri gerekir. 
Tür değişimi, Türkçede "eklenme" ya da "birleşme" yoluyla gerçekleşir. Birleşme yolu, Türkçede ad+ eylem ya da eylem+eylem biçiminde gerçekleşir. Bunların yardımcı unsurları, zaman içinde önce anlamsal boşalmaya, sonra da ekleşmeye başlar. +i- biçim birimi, er- yardımcı eyleminden dilbilgiselleşerek ekleşmiştir. Bu biçim birimin dizimi Eski Türkçedeki AD+ER-ZAMAN+Kiş̧i birleşik eylem dizimiyle aynıdır. Bu tarihi gelişim sonunda dizimdeki $\boldsymbol{e r}$ - eylemi ekleşmiş; dizimi $\boldsymbol{A D}+\dot{\boldsymbol{I}}$ ZAMAN+KIŞ̧í biçimine dönüşmüştür; yani yardımcı eylem sadece ekleşmiş; fakat dizim ve işlev bakımından $\boldsymbol{e r}$ - eyleminden farklılaşmamıştır. Bu nedenle, ad tümcelerinde nesne, uzaklaşma ve yaklaşma bildiren yer tamlayıcıları bulunmaz. Tıpkı çekimli durum eylemlerinin yüklem olduğu tümcelerdeki gibi.

Er- eylemi dilbilgiselleşme sürecinde en son aşama olan ses indirgenmesi aşamasını tamamlayıp ek haline gelmek üzere olsa da $+\boldsymbol{i}$ - biçim biriminin durum eylemi olma özelliğini sürdürdüğü araştırmacıların tespitlerinden de anlaşılmaktadır. Bu biçim birim ad ve ad gruplarına eklenerek onların türlerini değiştiren ve yüklem olmalarını sağlayan bir ek olarak çalışmaktadır. Bu anlamda $+\boldsymbol{i}$ - biçim birimi, $\boldsymbol{a d}+\boldsymbol{e r}$ - şeklindeki birleşik eylem yapısından çıkarak $\boldsymbol{a d}+\boldsymbol{i}$ - şekline ulaşan bir ektir ve adları eylem yapar ve yüklem görevini almalarını sağlar.

\begin{tabular}{|c|c|c|}
\hline & ORHUN TÜRKÇESİ & TÜRKIYE TÜRKÇESİ \\
\hline 1. & $\begin{array}{l}\text { bäglik urr ogluy kul bol-th, essilik kzz ogluy küy } \\
\text { boltn. (Tekin, 1995, s. 44) (KT D 24) }\end{array}$ & $\begin{array}{l}\text { Bey olmaya layık erkek çocukların köle oldu, } \\
\text { hanım olmaya layık kız çocukların cariye oldu. }\end{array}$ \\
\hline 2. & $\begin{array}{l}\text { çıañ bodunug bay kaltum, az bodunug üküs } \\
\text { kalthm. (Tekin, 1995, s. 36)(KT G 10) }\end{array}$ & $\begin{array}{l}\text { "Yoksul halkı zengin kzldım, az halkı çok } \\
\text { kzldim." }\end{array}$ \\
\hline 3. & türük bodun āçärti. (Tekin, 1995, s. 76) (BKD 38) & Türk halkı aç idi/açtr. \\
\hline
\end{tabular}

1. ve 2. tümcelerdeki AD+YARDIMCI EYLEM+ZAMAN+KIŞ̧̇ şablonu, adlarla kurulmuş birleşik eylemleri göstermektedir. Bu yapılar birleşik eylem olarak kabul edilir ve yüklem oldukları tümceler, eylem tümcesi olarak değerlendirilir. Burada bir adın yardımcı eylem aracılı̆̆ıyla eyleme çevrilmesi, zaman ve kişi eklerini alabilmesini sağlaması onun eylem tümcesi olarak değerlendirilmesine engel olmaz. Benzer şablon, 3. tümcedeki örnekte er- yardımcı eylemiyle yapılır. Burada er-, diğer yardımcı eylemlerle aynı işlevdedir ve tümce türü olarak eylem tümcesi olarak değerlendirilir.

Türkiye Türkçesinde ol-, kal-, et- yardımcı eylemleri ile kurulan birleşik eylemlerin yüklem olduğu tümceler, eylem tümcesi olarak kabul edilir. Bunun yanında, er- eyleminden gelişen ve adların yüklemleşmesi için zaman ve kip ekleri almasını sağlayan $+\boldsymbol{i}$ - biçim birimi, ad+i-zaman+kişi diziminde aynı işlevde kullanılırken içinde yer aldığı tümce, eylem tümcesi olarak değerlendirilir. Ad tümceleri hakkında bilgi verirken Ergin’in ifadeleri bu konuda dikkat çekidir:

"Bir fiil unsuru ihtiva etmesi itibariyle, şüphesiz isim cümlesi de bir fiil tümcesinden başka bir şey değildir. Onun için bu cümleyi bir fiil cümlesinden ayrı bir şey sanmamak, bu cümlenin fiil cümlesinin hususî bir şekli olduğunu unutmak lâzımdır.” (2002, s. 403)

Benzer bir görüş, "cevher fiil, bir durum fiilidir.” şeklinde Banguoğlu tarafından da dile getirilmiştir (1995, s. 535).

Buna rağmen eylem+eylem ve $\boldsymbol{a d}+\boldsymbol{e y l e m}$ biçiminde kurulan bütün birleşik eylem yapıları eylem tümceleri olarak değerlendirilirken $+\boldsymbol{i}$ - biçim birimiyle eylemleştirilip yüklem görevine 
getirilen adların bulunduğu tümceler ad tümcesi olarak değerlendirilmiştir. Halbuki, +i- biçim biriminin, adı eyleme dönüştürme ve yüklemleştirme işlevi neredeyse tüm araştırmacılar tarafından kabul edilmiştir; ancak bunların eylem tümcesi olduğu konusunda itirazlar daha önce ortaya koyulmuştur:

Delice "Yüklem Olarak Türkçede Fiil” adlı çalışmasında eylem ve yüklem kavramlarını ayrıntılı bir şekilde inceler. Tümcenin tek temel unsuru olarak belirdiği yüklemin oluşması için sözcük türü olarak kip ve kişi anlamı yüklenmiş bir eylem olması gerekliliğini tespit eder. Eylem dışındaki sözcüklerin yüklem olacaklarsa mutlaka yardımcı eylem ya da $\boldsymbol{e r}$-yardımcı eyleminden gelişen $+\boldsymbol{i}$ - biçim birimini alarak eyleme dönüştürülmeleri gerektiği; böylece tümcede iş, oluş, bildiri ya da haber bildirme özelliği iletebileceklerini ifade eder. Bugün bildirme ekleri olarak sınıflandırdığımız Eski Türkçede er- ve turolarak bulunan yardımcı eylemler, adları sözdizimi içinde yüklem yapmakla görevli olduklarını ve böylece yüklemde bulunması gereken kip ve kişi kavramını verdilerini belirtir. Delice'ye göre, eylem ve ad kökleri ayrılır: ad kökleri her eki alabilirken eylem kökleri tümceyi kuran ekleri de alabilmektedir. Bu nedenle eylemler, kavram adlandırma konusunda verimli bir sözcük türü değildir. Bu nedenle eylemler, yüklemi söz diziminde diğer sözcüklerle uyumlu kllacak ekleri almak zorundadır ve bu ekler bu nedenle söz dizimseldir. Eylemin kılınışını belirginleştirmek için kip ekleri, basit ve türemiş eylemlere doğrudan getirilir ve birleşik eylemlerde eylemin zamanını bildiren ekler de yardımcı eyleme getirilir. Sözcük türü olarak eylemin, adlardan gerek yapı gerekse kullanım açısından diğer sözcük türlerine göre ayrıldığı sonucuna varan Delice, son tahlilde şu yüklemin muhakkak eylem olması gerektiğini savunur (2002, s. $188,193,207,208)$.

Uğurlu da "Birleşik Fiiller" adlı çalışmasında +i- biçim birimini mastar olarak anlamsız bir eylem olarak değerlendirir. Adlara gelerek onları yüklemleştirdiğini ve çekimli eylemler oluşturduğunu belirler. Ona göre ek eylem olarak adlandırılan $+\boldsymbol{i}$ - biçim biriminin görünen yapısını açılar. Bu görünen yapılar üzerinden yazılan dilbilgilerinin yetersiz olduğunu ifade eder ve anlamadan ezberlemeye yol açtığını savunur. Çalışmalarda +i- biçim birimi ile ilgili anlatılanların çelişkili olduğunu söyler. Bir yanda ad tümcesi kabulü varken diğer yanda da ek eylemin işlevi adlara gelen $+\boldsymbol{i}$ biçim birimi aracılığıyla adların eylemleştirilmesi işlevinin olduğunu söyler. Uğur; birleşik eylem, ek eylem ve ad tümcesi konusunda söylenenlerin çelişkili ve muğlak olduklarını belirterek bunun "Türkçe dilbilgisinin insan mantığıyla uyuşmayan, anlaşılmayan kurallardan ibaret olduğu" algısına yol açtı̆̆ı sonuca varır. Sorunun söz konusu kavramların anlamı ölçüt alınarak açılanmasından kaynaklandığını savunur ve bu kavramların açılanmasında kullanılması gereken ölçütlerin yapı ve dizim olması gerektiğini ileri sürer. +i- biçim birimiyle kurulan yapıların "birleşik eylem" olarak değerlendirilmesini önerir. Buradan yola çlkarak bu biçim birimin kullanıldığı tümcelerin eylem tümcesi olarak kabul edilmesi gerektiğini söyleyerek "Türkçede bir tek, çekimli fiil ile kurulan yüklem çeşidi vardır; dolayısıyla isim cümlesinden söz edilemez." sonucuna varır (2009).

Leyla Karahan, "Türk Gramerciliğinde İsim Cümlesi-Fiil Cümlesi Tartışmaları" adlı çalışmasında ad tümceleri ve eylem tümceleri üzerinde tartışır; ama çalışmanın asıl odağı hangi tümce türünün aslî olduğudur. Vardığı sonuçta hem ad hem de eylem tümcesinin Türkçenin aslî tümceleri olduğunu söyler; ancak Türkçede ad tümcesi yoktur ya da vardır gibi bir sonuca da ulaşamamıştır (2015, s. 8).

Yapacağımız her değerlendirme, bakış açımıza göre değişebilir; ancak tümcenin bir yığın değil bir bir sistem, bir dizim olduğu ve anlamın iletilmesinde bir araç olduğu düşünülürse o anlamın iletilişindeki yapı göz önünde tutulmalıdır. Burada biçim birimlerin dizimdeki rolleri anlamsal olarak değil yapısal ve dizimsel olarak ele alınmalıdır. Şu unutulmamalıdır ki aynı yapı, içinde kullanılan sözcüklerin 
içeriklerine bağlı olarak farklı anlamlar iletebilecekken farklı yapılar aynı anlamları yansıtabilir. Bu durumda bu tip ikilemlerin içinden çıkabilmek için anlam oldukça kaypak bir zemine dayanmaktadır. Söz dizim dizgesi yapısal ölçütlerle açıklanmalıdır.

Dil, durağan bir yapı değildir. Tarih içinde gelişecek ve değişecektir. Bir dönemde anlamsal ve yapısal olarak farklı olan bir biçim birim başka bir dönemde farklılaşabilecektir. Şimdiki zaman eki, +lA vasta veya birliktelik eki ve daha birçok ekin sözcüklerden, anlamsal olarak içi boşalarak eklere dönüştüğü kabul edilirken er- eyleminin $+\boldsymbol{i}$ - biçim birimine aynı yolla dönüştüğünü kabul edip bu biçim birime ek eylem demek bir çelişkidir. Eski Türkçede er- eylemi bir yardımcı eylem olarak kabul edilebilir; ancak günümüzde anlamsal bir içeriği olmayan ve diğer ekler gibi bir sözcüğe eklenen ve görevini belirleyen $+\boldsymbol{i}$ - biçim birimine eylem demek eş zamanlılık ilkesine aykırıdır. Bu bakış açısıyla aslında $+\boldsymbol{i}$ - biçim biriminin yorumundan başka bir şey değişmez. Her iki tümce de eylem tümcesidir.

Yine, eş zamanlılık ilkesiyle çelişmeyen; ancak mantıksal olarak çelişik bir durum oluşturarak ad+yardımcı eylem şekilde oluşturulan birleşik eylemlerin yüklem olduğu tümcelere eylem tümcesi denirken, $\boldsymbol{a d}+\boldsymbol{i}$ - biçim birimi ile kurulmuş yüklemleri ad tümcesi saymaktır. Madem $+\boldsymbol{i}$ - biçim biriminin görev tanımında adları yüklem görevine sokmak, onların kişi ve zaman eklerini almasını sağlamak var ve yine yüklem kişi ve zamana bağlanmış bir eylem olmalı, öyleyse bu tip tümceler de eylem tümcesidir.

\section{Sonuçlar}

Tümcenin asıl öğesi yüklemdir ve yüklem, kişi ve zamana bağlı sözcüktür. İş, kılış, oluş ve durum bildiren sözcükler eylemdir. Eylem, Türkçede yüklem görevine giren sözcüktür. Tür açısından kesin ayrımları bulunan Türkçede bir eylemin bir adın görevine girmesi ya da bir adın bir eylemin görevini alabilmesi için tür değiştirmesi gerekir. Bu nedenle adlar yüklem olmak için tür değiştirmelidir. Bunun için ya ek ya da bir yardımcı eyleme gerek duyulur. +i- biçim birimi adları yüklem yapan bir ektir.

Bu dizimlerin bazılarında yardımcı öğeler dilbilgiselmiş ve bu dilbilgiselmiş biçim birimler günümüzde ekleşmiştir. Yapım ve çekim eki olarak değerlendirilmektedir. Eski Türkçede er- eylemi yardımcı bir eylem olarak ad+yardımcı eylem biçiminde birleşik eylemler oluşturur. Bu dönemde birleşik eylem olarak kabul edilmeleri doğrudur. Günümüzde er- eylemi bağımsız ve anlamlı bir biçim birim olarak yaşarken bu eylemden gelişmiş $+\boldsymbol{i}$ - biçim birimi dilbilgiselleşme sürecini tamamlamak üzere olan bir ek olarak varlığını sürdürür. $+\boldsymbol{i}$ - biçim birimine bir sözcük olarak muamele etmek eş zamanlılık ilkesine aykırı görünmektedir. $+\boldsymbol{i}$ - biçim birimi ile Eski Türkçe $\boldsymbol{e r}$ - yardımcı eyleminin işlev olarak aynı olmaları ikisinin de aynı şekilde adlandırılmasını ve muamele edilmesini gerektirmez.

Birleşik eylem dizimi, adlar ve eylemler için aynı şekilde işlemektedir. Ad+Yardıme eylem ya da eylem+ eylem dizimindedir. Eylem ve eylem diziminde olanlarda eylem, bir ortaç ya da ulaçla isimleştirilir ve asıl ya da yardımcı bir eylemle birleştirilir. Ad+Yardımcı eylem biçimindekiler eylem+eylem biçimindekiler gibi eylem tümcesi kabul edilir. Ancak ad+i- dizimindeki yapılar $\boldsymbol{a d}$ tümcesi olarak kabul edilmektedir. ad+i-biçim biriminin bulunduğu dizimler ister birleşik eylemler olarak kabul edilsin ister $+\boldsymbol{i}$ - biçim birimi bir ek olarak kabul edilip ada yüklem görevi yüklediği kabul edilsin eylem tümcesidir.

$+\boldsymbol{i}$ - biçim birimi, ek eylem ya da yardımcı eylem değildir. Bu biçim birim bir ektir. $+\boldsymbol{i}$ - biçim birimi bir ek olarak değerlendirilmeli, “yüklemleştirici” ya da Delice'nin önerdiği gibi “yüklem durum 
$\boldsymbol{e k i ”}$ olarak adlandırılmalıdır. Yüklemi, ad+i- biçim birimi şeklinde kurulmuş tümceler eylem tümcesi kabul edilmelidir. Tarihî ya da modern Türkçede, yapısal ve dizimsel olarak ad tümcesi kabul edilemez. Aksi taktirde bütün tanım ve sınıflandırmalarımız çelişkili görünecektir.

\section{Kisaltmalar}

$\begin{array}{ll}\boldsymbol{K T} & \text { Kül Tigin } \\ \boldsymbol{B K} & \text { Bilge Kağan } \\ \boldsymbol{D} & \text { Doğu } \\ \boldsymbol{G} & \text { Güney } \\ \boldsymbol{K B} & \text { Kutadgu Bilig } \\ \boldsymbol{N F} & \text { Nehcü'l-Ferādīs } \\ \mathbf{Y Z} & \text { Yūsuf u Zelīhā }\end{array}$

\section{Kaynakça}

Aksan, D. (1989). Her Yönüyle Dil- Ana Çizgileriyle Dilbilim (Cilt 2). Ankara: TDK Yayınları.

Aktan, B. (2009). Türkiye Türkçesinin Söz Dizimi. Ankara: Gazi Kitabevi.

Atabay, N., Özel, S., \& Çam, A. (2003). Türkiye Türkçesinin Sözdizimi (2. b.). İstanbul: Papatya Yayincilik.

Ayrancı, B. B. (2017). Cümle Problemlerine Dair Bir Alan Yazın Araştırması. Route Educational and Social Science Journal Volume, 4(6), 392-417.

Banguoğlu, T. (1995). Türkçenin Grameri (4. baskı b.). Ankara: TDK Yay.

Baydar, T. (2013). İsim+ Yardımcı Fiil Şeklinde Oluşan Birleşik Fiiller Üzerine. Atatürk Üniversitesi Türkiyat Araştırmaları Enstitüsü Dergisi, 49, 55-66.

Delice, H. İ. (2000). Türk Dilinde İşlevsel Ek Tasnifi Denemesi. Cumhuriyet Üniversitesi Fen Edebiyat Fakültesi Sosyal Bilimler Dergisi(24), 221-235.

Delice, H. İ. (2002). Yüklem Olarak Türkçede Fiil. C.Ü. Sosyal Bilimler Dergisi, 26(2), 185-212.

Delice, H. İ. (2007). Türkçenin Sözdizimi. İstanbul: Kitabevi Yayınları.

Delice, H. İ. (2008). Sözcük Türleri. Sivas: Asitan.

Delice, H. İ. (2012). Cümle Nasıl Tanımlanmalıdır? Turkish Studies International Periodical For the Languages, Literature and History of Turkish or Turkic, 7(1), 37-40.

Delice, H. İ. (2012). Sözcük Türleri Nasll Tasnif Edilmelidir? Turkish Studies - International Periodical For The Languages, Literature and History of Turkish or Turkic, 7/4(Fall), 27-34

Eckmann, J. (1995). Nehcü'l-Feradis Uştmahlarnın Açuq Yolı Cennetlerin Açık Yolu, I Metin, II Tıpkıbasım. (S. TEZCAN, \& H. ZÜLFIKAR, Dü) Ankara: TDK.

Ediskun, H. (1992). Türk DilBilgisi. İstanbul: Remzi Kitabevi.

Eker, S. (2011). Çağdaş Türk Dili (7. baskı b.). Ankara: Grafiker Yayınları.

Ergin, M. (2002). Türk Dil Bilgisi. İstanbul: Bayrak Basım, Yayım, Dağıtım.

Erkul, R. (2007). Cümle Metin Bilgisi (2. b.). Ankara: Anı Yayıncılık.

Gece, K. M. (1993). Türkçe Sözdiziminin Temel Mantığı. Ondokuz Mayıs Üniversitesi Eğitim Fakültesi Dergisi, 8(1), 97-104.

Gedizli, M. (2013). Türkçede Yardımcı Fiillerin Morfo-Semantiği ve İşlevi. Turkish Studies International Periodical For The Languages, Literature and History of Turkish or Turkic, 8(13), 897-914. 
Gencan, T. N. (2001). Dilbilgisi. Ankara: Ayraç.

Grönbech, K. (2000). Türkçenin Yapısı. (M. Akalın, Çev.) Atatürk Kültür, Dil ve Tarih Yüksek Kurumu.

Gülsevin, G. (1997). Türkiye Türkçesindeki Zaman ve Kip Çekimlerinde Birleşik Yapılar Üzerine. Türk Dili Araştırmaları Yıllığı Belleten, 215-224.

Gülsevin, G. (2004). Türkçede 'Sıra Dışı Ekler' ve Eklerin Tasnif-Tanımlanma Sorunu Üzerine. V. Uluslararası Türk Dili Kurultayı (20-26 Eylül 2004) Bildirileri . I, s. 1267-1284. Ankara: TDK .

Gündoğdu, V. K. (2016, Bahar ). Tuvacada Bir Gramerleşme Örneği: Deerzi. Dil Araştırmaları(18), 187198.

Johanson, L., \& Csató, É. (Dü). (1998). Turkic Language. Routledge.

Karaağaç, G. (2011). Türkçenin Sözdizimi (4. baskı b.). İstanbul: Kesit Yayınları.

Karabeyoğlu, A. R. (2007). Orhon Yazıtları'nda Bol- ve Er-Fiilleri Üzerine. Türklük Bilimi Araştırmaları, 22(22), 87-100.

Karademir, F. (2015). Türkçede İsim Cümlesi ve Alabildiği Ögeler Üzerine. Journal of International Social Research, 8(41).

Karahan, L. (2007). Türkçede Söz Dizimi (12.baskı b.). Ankara: Akçă̆ Yayınları.

Karahan, L. (2015). Türk Gramerciliğinde İsim Cümlesi-Fiil Cümlesi Tartışmaları. Prof. Dr. Mehmet Özmen Adına Sözdizimi Çalıştayı Bildirileri, (s. 1-8). Karahan Kitabevi.

Korkmaz, Z. (1992). Gramer Terimleri Sözlüğ̈̈. Ankara: TDK Yayınları.

Korkmaz, Z. (2009). Türkiye Türkçesi Grameri -Şekil Bilgisi-. Ankara: TDK Yay.

Krueger, J. R. (1961). Chuvash Manual (Introduction, Grammar, Reader and Vocabulary). Indiana : Indiana University Publications Uralic and Altaic Series Vol. 7.

Öner, M. (1999). Türkçede Edatlı (Sentaktik) İsim Çekimi. Türk Dili(565), 10-18.

Öner, M. (2004). Türkçe Söz Diziminde Eklenme Yönündeki Yapılar Üzerine . Zeynep Korkmaz Armağanı (s. 283-289). içinde Ankara: TDK Yayınları.

Öner, M. (2006). Türkçede İsimden Fiil Yapımı Üzerine Notlar. Modern Türklük Araştırmaları Dergisi, $3(1), 60-76$.

Öner, M. (2016). Genel Türkçede Ekleşen Yardımcı Fiiller (Gramerleşme Üzerine Tarihî-Karşılaştırmalı Bir İnceleme). XI. Uluslararası Büyük Türk Dili Kurultayı Bildirileri Kitabı 26-27 Eylül 2016 Budapeşte - Macaristan “İ. D. Doğramacı Bilkent Üniversitesi", (s. 9-14).

Özalan, U. (2014). Türk Dilinin Çağdaş Diyalektlerinde Cevherî Ek Fiil Olarak +(B)O(L)-. TÜRÜK- Dil, Edebiyat ve Halkbilimi Araştırmaları Dergisi, 2(3), 6-31.

Özezen, M. Y. (2010). Türkçede Bildirme Çekimi ve Pekiştirme-Olasılık Kategorisi. Ankara Üniversitesi Dil ve Tarih-Coğrafya Fakültesi Türkoloji Dergisi , 17(2), 187-196.

Özkan, M., \& Sevinçli, V. (2013). Türkiye Türkçesi Söz Dizimi. İstanbul: Akademik Kitaplar.

Öztürk, R. (2003). Eski Osmanlıcada ve Türkmencede "İdük" Yapısı. İlmî Araştırmalar (16), 77-85.

Paçacıoğlu, B. (1987). Türk Dili Dersleri. Sivas: Cumhuriyet Üniversitesi Yayuınları.

Sarıca, B. (2015). Türkçe Cümle Bilgisi. Ankara: Anı Yayıncılık.

Sezer, A. (1979). Türkçe Tümcelerde Sözdiziminin İşlevi. Genel Dilbilim Dergisi, 2(5-6), 53-63.

Şeyyâd Hamza. (2008). Yusūf u Zelihā. (Ü. Demirci, \& Ş. Korkmaz, Dü) İstanbul: Kaknüs Yayınları.

Tekin, T. (1995). Orhon Yazıtları Kül Tigin, Bilge Kağan, Tunyukuk. İstanbul: Simurg.

Tekin, T. (1997). Türkçenin Yapısı ve Eşsesli İsim-Fiil Kökleri. Türkoloji Eleştirileri (s. 50-66). Ankara: Simurg. 
Tekin, T. (2003). Orhon Türkçesi Grameri. İstanbul: TDAD.

Turan, Z. (2013). Zaman Eki Unsurunun Tayinine Ağızlardan Tanıklar . Türük Dil, Edebiyat ve Halkbilimi Araştırmaları Dergisi, 1(1), 133-144.

Uğurlu, M. (2009). 'Birleşik Fiil’ Üzerine. H. Develi (Dü.), İstanbul Kültür Üniversitesi Uluslararası Türk Dili ve Edebiyatı Kongresi [UTEK 2007-27-28 Ağustos 2007] Bildiriler Türkçenin Söz Dizimi ve Türk Edebiyatında Üslûp Arayışları. içinde I, s. 27-28. İstanbul: İstanbul Kültür Üniversitesi .

Uzun, N. E. (2004). Dünya Dillerinden Örnekleriyle Dilbigisinin Temel Kavramları: Türkçe Üzerine Tartışmalar. Kitap Matbaası.

Vural, H. (2013). Türkçede Yardımcı Fiil-Ek Fiil Meselesi ve Bir Terim Önerisi. Sosyal Bilimler Araştırmaları Dergisi, II, 42-49.

Yener, M. L. (2007). Türk Dilinde Sözcük Türleri Tasnifi Sorunu Üzerine / On the Problem of Part of Speech in Turkish Language. Turkish Studies - International Periodical for the Languages, Literature and History of Turkish or Turkic-, (Tunca Kortantamer Özel Sayısı 1), 2/3 (Summer), 606-623.

Yusuf Has Hacib. (2007). Kutadgu Bilig-Metin (Cilt 1). (R. R. Arat, Dü.) Ankara: TDK. 